\title{
Is Constitutional Pluralism (Il)liberal? On the Political Theory of European Legal Integration in Times of Crisis
}

\author{
Hugo Canihac* (D) \\ FRS-FNRS Researcher, University Saint-Louis, Brussels \\ *Corresponding author: hugocanihac@gmail.com
}

(Received 01 July 2020; accepted 20 July 2020)

\begin{abstract}
This Article uncovers the normative political theory underlying the legal doctrine of constitutional pluralism, as it is used in the EU today. Constitutional pluralism, once described as a semi-official legal doctrine in the $\mathrm{EU}$, is now being used by some member states to challenge its authority and rules. By reconstructing the political thought of one of its founders, N. MacCormick, this Article takes issue with two most common interpretations of constitutional pluralism: On the one hand, it has been claimed that the normative political content of constitutional pluralism is virtually identical, or at least compatible, with that of Kantian rights-based cosmopolitanism; on the other, it has been contended, especially with regard to its uses in Hungary and Poland, that it was an inherently dangerous, illiberal, normative theory. This Article offers to move away from current legal debates to go back to the origins of constitutional pluralism. It argues that constitutional pluralism is not a purely liberal theory indeed. But neither is it inherently illiberal. Rather, both liberal and illiberal readings are possible, but partial, interpretations of MacCormickian constitutional pluralism. A more systematic interpretation shows that constitutional pluralism opens a path to move beyond this somewhat archetypical divide.
\end{abstract}

Keywords: Constitutional pluralism; European union; illiberalism; Neil MacCormick; political liberalism; post-sovereignty

\section{A. Introduction}

The European Union (EU) faces a strange paradox: What was once described as a semi-official legal doctrine in the EU is being used by some member states to challenge its authority and rules. Indeed, since the early 1990s, a remarkable theory has made its way into European legal debates: Constitutional pluralism. Forged as a reaction to the legal situation raised by the Maastricht Treaty, and to the "Maastricht" ruling of the German Federal Constitutional Court (FCC), constitutional pluralism was, foremost, an attempt to describe the European legal order as a system of intertwined and interdependent legal norms in which there is no ultimate, comprehensive authority-no sovereign, in the modern sense. ${ }^{1}$ In this post-sovereign order, authority is dispersed across different sites, and neither the EU nor the member states can claim the right to have the "final word" on every subject. Rather than relations of hierarchical subordination, such an order is

\footnotetext{
Hugo Canihac is a post-doctoral researcher at University Saint-Louis (Brussels) and lecturer at Sciences Po (Reims). He holds a PhD in Political Science from Sciences Po Bordeaux, a Master of Arts in Political Science from Institut d'Etudes Politiques de Bordeaux, and a Master of Arts and Bachelor of Arts in Philosophy from Université Bordeaux Montaigne.

${ }^{1}$ See generally Neil MacCormick, Beyond the Sovereign State, 56 MoD. L. REv. 1 (1993); Neil Walker, The Idea of Constitutional Pluralism, 65 Mod. L. Rev. 317 (2002); Constitutional Pluralism In the European Union AND BeYond (Matej Avbelj \& Jan Komárek eds., 2012); Klemen JaKlic, Constitutional Pluralism IN THE EU (2013); Symposium, Crisis and Constitutional Pluralism in the European Union, 21 CAmbridge Y.B. Eur. Legal STUD. 3 (2019). 
heterarchical; it rests on the cooperation between its different components that preserve their separate constitutional identity. Although it was largely criticized at first, as it seemed to endanger the long-established primacy of EU law, this doctrine has come to enjoy a growing popularity among EU lawyers. ${ }^{2}$ It has been explicitly endorsed by prominent members of the European Court of Justice (ECJ), such as the former Advocate General Miguel P. Maduro, and its President, K. Lenaerts. ${ }^{3}$ Increasingly, constitutional pluralism has become accepted as a legitimate doctrine of EU legal integration, best expressing its values of mutual respect and sincere cooperation.

Yet, more recently, other uses of constitutional pluralism have emerged. In the name of constitutional pluralism and of the closely associated concept of constitutional identity, courts and governments of several member states have contested the primacy of EU rules and the authority of EU institutions. In Germany, for instance, the recent jurisprudence of the FCC concerning fundamental rights has been analyzed in pluralist terms, ${ }^{4}$ while the recent ruling on the European Central Bank policies has also been framed in terms of protecting the country's constitutional identity. ${ }^{5}$ But above all, this use has been echoed in states ruled by illiberal governments. In Hungary, the Constitutional Court has defied EU migration rules in its name. In Poland, the much-contested reform of the judicial system has been justified through explicit references to constitutional pluralists. ${ }^{6}$ The doctrine of constitutional pluralism has become part of the repertoire of conceptual and judicial tools used to undermine the EU's authority and justify illiberal policies. This has led some critics to reject constitutional pluralism altogether, arguing that it is "inherently dangerous."7 While this might not have been the sincere intention of its first advocates, it allows autocrats to defend rules directly opposed to the EU's principles and values while remaining within the EU. Consequently, these critics claim, the descriptive doctrine of constitutional pluralism would conceal a normative illiberal core.

This Article is dedicated to examining this claim. Is it true that, at the heart of EU law, rests a normative theory breaking away from political liberalism? Political liberalism is understood to be a family of political thought emphasizing the ideas of individual freedom and rights, social contract, limited government through law, and a "thin" ethos allowing for the expression and toleration of a plurality of beliefs and values. In its international dimension, liberalism has generally been associated with cosmopolitan plans of "peace-through-law" of Kantian inspiration. ${ }^{8}$ By contrast, the more elusive concept of illiberalism has come to mean regimes that reject all, or most, of these ideas. These regimes tend to prefer a more authoritarian rule, are hardly compatible with respect for the rule of law, praise a "thick" ethos, understood as the expression of a preexisting definite community, and leave little room for the toleration of diverse beliefs and values.

\footnotetext{
${ }^{2}$ See Joseph Weiler, Prologue: Global and Pluralist Constitutionalism - Some Doubts, in ThE WORLDS OF EUROPEAN CONSTitutionalism 8 (Grainne de Burca \& Joseph Weiler eds., 2012).

${ }^{3}$ See Ana Bobic, Constitutional Pluralism is Not Dead: An Analysis of Interactions Between Constitutional Courts of Member States and the European Court of Justice, 18 German L.J. 1395 (2017); Miguel Maduro, Three Claims of Constitutional Pluralism, in Constitutional Pluralism in the European Union AND Beyond (Matej Avbelj \& Jan Komárek eds., 2012); Koen Lenaerts, EU Values and Constitutional Pluralism: The EU System of Fundamental Rights Protection, 34 POLISH Y.B. INT'L L. 135 (2014).

${ }^{4}$ See Matej Avbelj, The Federal Constitutional Court Rules for a Bright Future of Constitutional Pluralism, 21 GERMAN L.J. 27 (2020).

${ }^{5}$ See BVERFGE, 2 BvR 859/15, May 5, 2020, https://www.bundesverfassungsgericht.de/SharedDocs/Entscheidungen/EN/ 2020/05/rs20200505_2bvr085915en.html.

${ }^{6}$ See R Daniel Kelemen \& Laurent Pech, The Uses and Abuses of Constitutional Pluralism: Undermining the Rule of Law in the Name of Constitutional Identity in Hungary and Poland, 21 CAmbridge Y.B. OF Eur. Legal Stud. 59 (2019); Jessica C. Lawrence, Constitutional Pluralism's Unspoken Normative Core, 21 CAmbridge Y.B. Of Eur. Legal STUD. 24-40, 10 (2019).

${ }^{7}$ Kelemen \& Pech, supra note 6, at 3.

${ }^{8}$ See John Rawls, Political Liberalism (2005). Here, I take John Rawls as a typicaleven though by no means exclusive representative of this tradition. On illiberalism in Europe, see Tímea Drinóczi \& Agnieszka Bień-Kacała, Illiberal Constitutionalism: The Case of Hungary and Poland, 20 GERMAN L.J. 140 (2019).
} 
Accordingly, on the international level, they are usually aggressive defenders of the nation-states. In this light, this Article argues that normatively, constitutional pluralism is not a purely liberal theory. Though neither is it inherently illiberal. Rather, I will show that both liberal and illiberal readings are possible, but partial, and by no means necessary interpretations of constitutional pluralism. In short, constitutional pluralism opens a path to move beyond this somewhat archetypical divide.

In order to show this, I offer to move away from current legal debates to harken back to the origins of constitutional pluralism. I will reconstruct the political thought of the Scottish legal philosopher, and eventually Member of the European Parliament (MEP), Sir Neil MacCormick (1941-2009), generally regarded as the founder of constitutional pluralism. For, as I will recall, constitutional pluralism was, in the beginning, as much a political theory as a legal doctrine. Examining the thought of MacCormick is not to say that all constitutional pluralists share the exact same political ideas or form a coherent school. But he provided one of the most original and coherent articulations of these ideas, not only as a theoretician, but also as a practitioner of European politics. In the first part of this Article, I will briefly recall the origins and central legal theses of constitutional pluralism as elaborated by MacCormick. I will then examine the liberal and illiberal interpretations of constitutional pluralism and the main critics addressed to them. Finally, I will show that both rest on partial readings of the theory. Constitutional pluralism is best understood as a hybrid theory, including liberal elements in combination with more communitarian and republican dimensions. Yet, this does not mean that the normative core of constitutional pluralism is inherently flawed and dangerously illiberal. Rather, in conclusion, I will suggest that this might be a way forward to address the contemporary crisis of political liberalism.

\section{B. What is Constitutional Pluralism? From Legal to Political Theory}

Since the beginning, constitutional pluralism was a political theory. It was an answer to a very specific political context, in which debates related to European integration and to the autonomy of regions within member states were linked together by MacCormick. Moreover, its legal arguments themselves called for a political reading of constitutional pluralism, going beyond strictly legal reasoning and devices.

\section{The Emergence of Constitutional Pluralism}

Constitutional pluralism was elaborated to describe the situation of European integration in the early 1990s. After decades of quiet but slow integration, during which the ECJ had asserted the primacy of European Community (EC) law over national law, from the mid-1980s, European institutions tried to rejuvenate the European project. Yet, this triggered a genuine constitutional crisis about institutional hierarchy in the EU. In the UK, for instance, the Factortame case, and the decisions of the ECJ it generated in 1990 and 1991, raised an important public debate about the continuing sovereignty of national legislative bodies in the EC and EU. Most importantly, the "Maastricht ruling" delivered by the FCC in 1993 was a landmark case: While authorizing the ratification of the treaty by Germany, the Court criticized, in the name of democracy and national sovereignty, the extensive interpretations of EC law and of its own competences produced by the ECJ since the 1960s. This judgment set the ECJ and the FCC on a potential collision course and directly challenged the authority of EU institutions over national bodies.

It is to account for this situation of competition between courts that MacCormick developed his post-sovereign thesis throughout the 1990s. It is worth noting from the outset that, until then, he was an almost complete outsider to the field of Community law. ${ }^{9}$ A distinguished legal philosopher, he had only limited encounters with Community law, then a mostly technical and narrow

\footnotetext{
${ }^{9}$ Law and Democracy in Neil MacCormick’s Legal and Political Theory: The Post-Sovereign Constellation, 7 (Agustín José Menéndez \& John Erik Fossum eds., 2011).
} 
field. Rather, his interest for European issues was greatly stimulated by his political engagement for Scottish nationalism. Due to his father, who was credited with creating and establishing the Scottish National Party (SNP), MacCormick was deeply involved in political matters early on. He himself joined the SNP in 1967. In the increasingly nationalist mood of the 1970s in Scotland, he authoritatively contributed to the political debates within the party, the executive body of which he became a member in 1978. After the failed independence referendum of 1978, the party's motto became "independence in Europe." 10 Instrumental in this change, MacCormick became even more politically active and contested elections throughout the 1980s, though losing all of them. This political experience, accumulated over the years, eventually led him to European politics. He would run and be elected as an MEP under the flag of the SNP in 1999. He then was appointed as an alternate member of the Convention on the future of Europe, in charge of drafting a Constitution for Europe. During the 1990s, MacCormick not only developed his theoretical interest for European integration, he also entered the game of European politics through Scottish nationalism.

\section{The Two Main Theses}

In this context, his theory was designed to escape the old opposition between federalists, advocating more powers to the EU, and national sovereigntists, defending the sovereignty of member states. To that aim, the theory MacCormick proposed can be summarized around two main theses. ${ }^{11}$ First, "the differentiated but equal standpoint thesis," stating the absence of supreme legal authority in Europe. And second, "the stability beyond sovereignty thesis," which is the idea that the stability of the European legal order is rooted on non-legal bases.

The "differentiated but equal standpoints" thesis directly confronted the idea of EC-EU law as a comprehensive supreme constitutional norm. MacCormick observed that, focusing either on states or on European institutions, both nationalists and federalists had a monocular view and thus provided an inadequate description of reality. ${ }^{12}$ Instead, in Hartian fashion, he analyzed the EU as exhibiting the coexistence of a multiplicity of legal orders without a "single source of power"-or, more precisely, without any order being in the position of claiming ultimate, all-encompassing supremacy over the others. It opened a path "to escape from the idea that all law must originate in a single power source, like a sovereign . . . to discover the possibility of taking a broader, more diffuse, view of law." ${ }^{13}$ In other words, one need not think about law as a pyramid but rather, as a network.

Thus, MacCormick concluded that, in a pluralist perspective, the German constitutional court was right to assert that the ECJ was not the ultimate authority in Europe. As he put it, "the doctrine of supremacy of Community law is not to be confused with any kind of all-purpose subordination of Member State law to Community law." 14 Yet, it was wrong to believe that such an ultimate authority remained in the hands of the German state, or the German people. The actual situation was one of non-hierarchical coexistence of different legitimate claims. Importantly, to characterize such a situation, he first endorsed "radical pluralism" - there is no sovereign nor comprehensive supreme norm at all. Eventually, however, he advocated a "pluralism under international law" all members of the international community are submitted to global legal norms—often regarded as a more conventional form of monism. ${ }^{15}$

\footnotetext{
${ }^{10}$ Jonathan Hearn, Claiming Scotland: National Identity and Liberal Culture (2000).

${ }^{11}$ See Augustin Menéndez, From Constitutional Pluralism to a Pluralistic Constitution? Constitutional Synthesis as a MacCormickian Constitutional Theory of European Integration, in LAW AND DEMOCRACY IN NEIL MACCORMICK's LEGAL And Political Theory 225 (Augustin Menéndez \& John Erik Fossum eds., 2011).

${ }^{12}$ MacCormick, supra note 1 , at 4 .

${ }^{13} \mathrm{Id}$. at 8 .

${ }^{14}$ Neil MacCormick, The Maastricht-Urteil: Sovereignty Now, 1 EUR. L. J. 259, 264 (1995).

${ }^{15}$ Neil MacCormick, Questioning SOVEREIGNTY: LaW, State, and Nation In THE European Commonwealth 118 (1999).
} 
In both versions of the theory, though, what mattered was to devise a way to secure the coexistence of the different member states and the EU in a peaceful manner. Therefore, while the first thesis defined the theoretical coordinates of constitutional pluralism, the "stability beyond law" thesis dealt with its practical conditions of possibility. The constitutional crisis was, after all, prompted by conflicts between courts, as well as political contestations of the democratic legitimacy of European integration. Any answer to this crisis would thus have to be able to provide a practical solution to these challenges. To do so, MacCormick suggested that we look beyond integration through law. Law cannot provide a solution to all legal and social conflicts. ${ }^{16}$ Instead, law needs to constantly be considered in its broader social and political context. This does not imply that law becomes an inherently political matter. On the contrary, he underscored that law and politics are two "distinct, but related" areas of social life. ${ }^{17}$ This, however, emphasized that certain problems require a political rather than legal solution; law is a tool of European integration, but its integrative power is limited. Accordingly, constitutional pluralism should not be regarded as preoccupied with legal concerns only. Rather, it needs to be understood as implying a political theory as well.

But what kind of political theory does constitutional pluralism call for? It is to the mainliberal and illiberal-interpretations of this political theory that I now turn.

\section{Constitutional Pluralism, Liberal or Illiberal?}

Commentators have rightly pointed out this political theoretical dimension of constitutional pluralism. Though its normative content has been bitterly disputed. Constitutional pluralism has been interpreted primarily in two differing ways. Some understand it as a deeply liberal theory, which, in the last instance, boils down to a cosmopolitan project of which the EU is the prefiguration. Yet, others have claimed it is inherently illiberal, which makes its uses by regimes such as Hungary or Poland understandable. Here, I will reconstruct the main features of these interpretations and show how each school of thought leads to serious criticisms of constitutional pluralism.

\section{A Liberal Reading: Rights-Based Cosmopolitanism Under a Different Name?}

A first interpretation in political theoretical terms of constitutional pluralism emphasizes its liberal dimension. This rests on the idea that a dispersal of sovereignty between several bodies among which none is in a position to claim comprehensive supreme authority limits the risk of authoritarian domination by a sovereign. Essentially based on the moderate form of pluralism, labeled "pluralism under international law," it regards the normative content of the theory as virtually identical, or at least compatible, with that of Kantian rights-based cosmopolitanism.

The starting point of this interpretation is the now widespread observation of a general constitutionalization of legal norms beyond the states. This constitutionalization process has long been acknowledged in European integration, where it has been fostered by the efforts of the ECJ to establish the primacy and direct effect of EC law since the 1960s. To the proponents of this interpretation, the constitutionalization of the international order is a matter of fact, which has important normative consequences. For, in such an order, individuals are protected by universalizable legal norms granting them rights beyond the polity to which they belong, that is, beyond the traditional divide between citizens and outsiders. ${ }^{18}$ Through this constitutionalization beyond the states, a new layer of transnational law and rights emerges.

\footnotetext{
${ }^{16}$ MacCormick, supra note 14 , at 265.

${ }^{17}$ MacCormick, supra note 1 , at 11 .

${ }^{18}$ See Mattias Kumm, The Cosmopolitan Turn in Constitutionalism: On the Relationship Between Constitutionalism in and Beyond the State, in Ruling The World?: Constitutionalism, International LaW, and Global Governance 272 (Jeffrey L. Dunoff \& Joel P. Trachtman eds., 2010).
} 
At the same time, however, it remains pluralist because it tolerates a diversity of particular expressions and interpretations of this relatively shared normative content, without any claiming absolute primacy. It recognizes that different historically developed cultural and political systems can allow for variations in the scope of the rights they grant, without any supreme authority being in a position to legitimately impose a single understanding. Instead, courts are to deal with the conflicts that may-and will-arise as a result of these differences. This is to say that dialogue between courts plays a deliberative democratic role that is crucial in the resolution of conflicts and in the legitimation of these norms. ${ }^{19}$ In short, as one of the proponents of this understanding put it, "Europe possesses an overarching 'constitutional' structure, comprised of fundamental rights and the shared authority of judges to adjudicate individual claims. No single organ possesses the 'final word' when it comes to a conflict between conflicting interpretations of rights; instead, the system develops through inter-court dialogue, both cooperative and competitive." 20

These ideas have been especially discussed in relation to the EU. Indeed, as the context of MacCormick's early reflections about constitutional pluralism suggests, it was perceived as useful to conceptualize the post-Maastricht situation in Europe. In spite of the reluctance of those who saw it as undermining the authority of the EU and its law, it could be interpreted as a way to reassert the constitutional status of EU law, while allowing for some diversity among EU members. But, as is demonstrated by its application to the analysis of international bodies beyond the EUsuch as the ECHR or the WTO-this reasoning is by no means limited to the EU. ${ }^{21}$ In fact, its advocates tend to see the constitutional pluralist order that developed in the EU as a forerunner of a more global order, sometimes directly presented as realizing Kantian ideas for international peace. ${ }^{22}$ In this sense, it becomes difficult to distinguish constitutional pluralism from rights-based liberal cosmopolitanism.

This interpretation of constitutional pluralism has consistently been attacked along the lines familiar to critics of rights-based liberal cosmopolitanism. It has been deemed too liberal in its appeal to the law and to rights to prove a satisfying normative ideal or to be sustainable in practice. A first line of criticism rejects it because of its democratic shortcomings: "Such a liberal constitutionalism consists of limitations against arbitrary power, but does not embody a broader project of collective self-government." ${ }^{23}$ Criticized here are the limitations that a constitutionalization of rights beyond the state imposes on democratic decision-making. Even if they are granted a democratic role, courts are neither direct nor representative democratic institutions. Therefore, a legitimate international order should be able to make room for more democratic procedures.

A second, if related, line of criticism against this interpretation of constitutional pluralism is even more devastating. It acknowledges its normative content, but claims that, ultimately, it fails to propose a consistent political theory. Here, too, constitutional pluralism is blamed for granting too much to the law and not enough to the political. Indeed, it "leads us down the path of total liberal individualism or of total legalization, albeit a total legalization masquerading as total constitutionalism." 24 In a Schmittian vein, it is argued that this would not only seriously damage collective systems of democratic decision-making, but more fundamentally lead to a suppression of the political itself. ${ }^{25}$

\footnotetext{
${ }^{19}$ See Miguel Maduro, Contrapunctual Law: Europe's Constitutional Pluralism in Action, in SOVEREIGNTY IN TRANSITION 526 (Neil Walker ed., 2003).

${ }^{20}$ Alec Stone Sweet \& Clare Ryan, A Cosmopolitan Legal Order: Kant, Constitutional Justice, and the European Convention on Human Rights 4 (2018).

${ }^{21}$ See generally Deborah Z. Cass, The Constitutionalization of the World Trade Organization: Legitimacy, Democracy, and Community in the International Trading System (2005).

${ }^{22}$ See STONe SweEt \& RyAn, supra note 20.

${ }^{23}$ Nico Krisch, Constitutionalism and Pluralism: A Reply to Alec Stone Sweet, 11 InT'L J. Const. L. 501,503 (2013).

${ }^{24}$ Martin Loughlin, Constitutional Pluralism: An Oxymoron?, 3 Glob. Constitutionalism 9, 29 (2014).

${ }^{25} \mathrm{See} I d$.
} 
Finally, such pluralism would prove inefficient, and even dangerous, to secure a peaceful international order. As the failure of interwar plans to establish peace through law should have made clear, such purely legal projects are necessarily weak. In particular, a post-sovereign order has been said to be unable to meet the challenge of crises. By crisis, critics meant an exceptional situation, in which legal arrangements might not exist or might be contestedeither because action on an emergency mode is required, or because conflict has arisen about which lawfully constituted body has the final say on the matter. In such a case, constitutional pluralism would either lead to chaos because nobody would possess the ultimate authority necessary to secure the enforcement of legal rules, or to the de facto domination of any country powerful enough to use the absence of a formally sovereign power to pursue its own interests. $^{26}$

\section{An Illiberal Reading: Constitutional Pluralism as "Thick" Nationalism}

A second reading of constitutional pluralism has gained traction in recent years. It interprets the theory as leading to, or at least compatible with, nationalist, illiberal policies. It is here that the pluralistic promise of independence from any higher sovereign authority is emphasized. Thus, this reading foremost resonates with the radical version of constitutional pluralism, which insists on the formal equality of the different claims to supreme power coexisting in the EU.

In its radical version, too, constitutional pluralism acknowledges the diversity of constitutional claims coexisting in the contemporary international order, and above all in the EU. But it goes further in demanding their strict equality. For instance, while there might indeed be something like a supranational constitution in the EU, it is not in a position of comprehensive supremacy over the national constitutions. The situation is rather one of complete "heterarchy," as opposed to the hierarchical submission to a superior rule or organization. This radical pluralist claim has been especially connected to a related, but distinct, concept. Indeed, national constitutions are said to express and protect the unique constitutional identities of the member states, as they have been shaped by their history, culture, and values. ${ }^{27}$ This identity might be thought of as primarily including the institutional framework of the regime and, in particular, its democratic character. It may also be conceived in substantive, even ethno-national terms. In this sense, national constitutions are directly grounded on the existence of a relatively clearly defined people (demos), whose identity they express and protect through legal means. Defending the equal status of national and supranational legal norms is justified by an appeal to a preexisting national identity to be protected.

Of course, as long as there is no disagreement between the different authorities and rules, this is of little practical relevance. But in case of conflict, it becomes of major significance. This was made clear previously by the FCC in its "Maastricht" ruling in 1993, for radical constitutional pluralism neatly captured its line of reasoning and has been repeated several times since. It connected the constitution, the democratic character of the Federal Republic of Germany (FRG), and the historical development of a shared culture and language. In so doing, it asserted that a member state can oppose European rules in the name of its own democratic self-definition. But while the FCC raised these concerns without taking the step to directly confront the EU and the ECJ, this has allowed for different, more conflictual uses to emerge. This has above all been the case in Hungary and Poland, where the avowedly illiberal regimes in place have used, or fostered, the same

\footnotetext{
${ }^{26}$ See Richard Bellamy, A European Republic of Sovereign States: Sovereignty, Republicanism and the European Union, 16 Eur. J. POL. THEORY 188, 203 (2017).

${ }^{27}$ See generally Constitutional Identity in a Europe of Multilevel Constitutionalism (Christian Calliess \& Gerhard van der Schyff eds., 2019).
} 
reasoning to defy the EU. Through the concepts of constitutional pluralism and constitutional identity, they have promoted a vision of nation and nationalism based on an ethno-national definition of national identity, said to be expressed in the constitution. This definition of the nation and its identity has come to conflict with the EU and its values, as in the case of the asylum crisis. Arguing that opening its border to refugees would be a breach against its national constitutional identity, the Hungarian government, in particular, was able to use constitutional pluralism as a legal tool to oppose EU rules. ${ }^{28}$

These uses have prompted criticism of radical constitutional pluralism as an inherently illiberal theory. Some have pointed out a dangerous link between nationalism and illiberalism established through the concept of constitutional identity. ${ }^{29}$ As we have seen, the nationalist potential of radical constitutional pluralism may be expressed in thick, ethno-national definitions of a country's constitutional identity. This leaves ample room for illiberal leaders to implement exclusionary policies based on ethno-national criteria, and put them at risk of conflicting with the liberal principle of non-discrimination as enshrined in the EU treaties. This not only endangers the authority of the EU but also its very existence as an organization based on shared values. Moreover, another line of criticism has concentrated on its implications for the rule of law. It has been claimed that radical constitutional pluralism simply amounts to refusing to acknowledge the authority of supranational rules over national ones. In so doing, it not only prevents a shared legal order from emerging. It also fundamentally endangers the very idea of the rule of law, as it is associated with legal predictability and uniformity. ${ }^{30}$ In this sense, it departs from a most basic liberal principle.

It is remarkable that constitutional pluralism has given birth to such opposite readings in political theoretical terms. While in the first case, it is made to look very much like a version of rightsbased cosmopolitanism, in the other it is interpreted as opening the path to a nationalist reading. One is criticized for being too liberal, that is, ineffective in practice to stabilize a viable international order and problematically restrictive on democracy. The other is blamed for not being liberal enough, potentially allowing for discriminatory policies to be implemented and directly endangering the rule of law. In the remainder of this Article, I will weigh these two interpretations against the thoughts of MacCormick. I will argue that both are partial, and that going back to his political theoretical conceptualization allows us to better grasp how he intended to prevent these possible dangers and abuses of constitutional pluralism.

\section{An Alternative Interpretation: Constitutional Pluralism as Republican Cosmopolitanism}

MacCormick did not shy away from the potential problematic implications of his legal theory. Rather, he directly engaged with them. To that aim, he developed an explicit political reflection, both theoretical and practical, during his time at the European Parliament (EP). This political theory is not of the pure liberal variety, as claimed by proponents of the first interpretation. Neither is it intrinsically illiberal, as the second interpretation indicates. This is not to say that the interpretations of constitutional pluralism outlined so far are completely inaccurate. They are permissible, but by no means necessary, readings of the theory developed by MacCormick.

In what follows, I contend that it is best understood as an attempt to reconcile a commitment to liberal values and a communitarian concern for concrete communities, such as nations. Ultimately, this composite theory is most likely to lead to a kind of republican cosmopolitanism. In order to demonstrate this, I will first consider MacCormick's institutional reflection about the $\mathrm{EU}$ and its democratic character, before turning to his thoughts about nations and nationalist

\footnotetext{
${ }^{28}$ See Lawrence, supra note 6, at 34.

${ }^{29}$ See Kelemen \& Pech, supra note 6, at 62; Julio Baquero CruZ, What's Left OF THE LAW OF INTEgRATION? DeCAY AND Resistance in European Union LAW 45-46 (2018).

${ }^{30}$ See BAQUero CruZ, supra note 29 , at 34.
} 
ethos. Finally, I will examine how he envisioned the problems of stability and legal predictability of a post-sovereign organization, especially in times of crisis.

\section{Democracy Through Subsidiarity}

A first observation should raise some doubts about the interpretation of MacCormick's constitutional pluralism as simply rearticulating the Kantian cosmopolitan project. MacCormick did not so much claim a Kantian filiation as a Humean one. ${ }^{31}$ Here is not the place to present Hume's much debated political thought in detail, but it should be at least noted that Hume can hardly be regarded as a typical liberal. ${ }^{32}$ For instance, he rejected the idea of an original social contract, while emphasizing historically developed conventions. Likewise, he famously avoided the language of rights typical of liberalism. Accordingly, I posit, MacCormick understood Hume as combining a liberal emphasis on limited government, and a republican ideal of participation and civic virtue of citizens. McCormick tried to convey this originality of Hume's thought by unearthing his old concepts of "mixed constitution" and, most importantly, his essay entitled the "Idea of a Perfect Commonwealth," 33 to conceptualize a post-sovereign organization such as the EU.

MacCormick argued that the EU as it is, is best analyzed as a mixed constitution. The characteristic institutional feature of a mixed constitution is its hybridity; it divides authority between institutions typical of different types of regimes. Likewise, the EU displays democratic features. It is, of course, thanks to its parliament and its numerous committees, in which public deliberation takes place. ${ }^{34}$ Moreover, its role should be understood in combination with that of national parliaments-they work together to channel the people's will and to control unelected organs. An additional democratic feature, albeit also indirect, is to be found in the Council, with Ministers representing the democratic will of national constituents. In sum, "it is not a system wholly lacking in democratic elements or democratic spirit." 35

But the EU is not only a democracy. This is because of its strong bureaucratic orientation. Modern bureaucracy, with its selection process based on merits and competence rather than on popularity or wealth, is somehow close to the original concept of aristocracy-as the "rule by the best [aristoi]." ${ }^{36}$ In the EU, for instance, the most bureaucratic institution, the Commission, is not democratically selected; its members are theoretically chosen because of their competence. This could easily be extended to most technical institutions, such as agencies or the European Central Bank (ECB). The EU is no pure democracy, but comprises aristocratic elements. In fact, as MacCormick-a Scottish republican-maliciously remarked, what is missing in this system is the "monarchical element." 37 This points to the lack of a public "head" in charge of representing the Union-an element somehow provided for since the Lisbon treaty by the President of the European Council.

This description of the EU as a mixed constitution is articulated to a normative assessment. A mixed constitution is a good system, although not the best possible. Indeed, as in the traditional understanding of a mixed constitution, the aristocratic and democratic elements "provide effective checks and controls upon degeneration into the vicious forms of any given type." ${ }^{38}$ In this sense, a

\footnotetext{
${ }^{31}$ See MACCORMICK, supra note 15 , at 180.

${ }^{32}$ See generally David Miller, Philosophy and ideology in Hume's political thought (1981).

${ }^{33}$ See David Hume, Idea of a Perfect Commonwealth, in Political Essays 221, \# (Knud Haakonssen ed., 1994).

${ }^{34}$ See Neil MacCormick, The European Union and the Idea of a Perfect Commonwealth, Address at the Hume Lecture (Mar. 1, 2006), in Hume OCCASIONAL PAPER No. 68, 2006, at 22-23, https://static1.squarespace.com/static/59b82ed532601e01a494df34/t/ 59de2da0a8b2b090a3971c14/1507732897110/HOP-68.-The-European-Union-and-the-Idea-of-a-Pefect-CommonwealthMacCormick.pdf.

${ }^{35}$ MACCORMICK, supra note 15 , at 147.

${ }^{36} \mathrm{Id}$. at 146.

${ }^{37} \mathrm{Id}$. at $148-49$.

${ }^{38} I d$. at $146-147$
} 
mixed constitution is able to deliver relative stability—because of the aristocratic element-while preventing authoritarianism-because of the democratic element. But this assessment should not be confused with an unqualified endorsement of the EU as it is. The EU might well be democratic enough for a mixed constitution, but "this is by no means democracy perfect or democracy complete." ${ }^{39}$ Thus, far from ignoring the question of democracy, he wondered how the mixed constitution of a post-sovereign EU could be improved to become more democratic.

How could the constitutional design of the EU be improved to become more democratic? To this aim, MacCormick relied on the Humean concept of a "perfect Commonwealth" as an ideal republican government in which a lot of power is devolved to local entities making up the great Commonwealth. ${ }^{40}$ In such a scheme, they retain the legislative power, which is exercised jointly with the other local entities. Similarly, MacCormick submitted that democracy in the EU could and should be greatly improved through the practice of subsidiarity introduced in the European legal vocabulary by the Maastricht Treaty. Subsidiarity is essentially a principle of devolution of power, asserting that decisions should be taken as close as possible to the people it concerns, so as to ensure maximum autonomy. He thus saw it as inherently democratic and as a practical solution to the "democratic disconnect" between the EU and the peoples of its member states. ${ }^{41}$

Indeed, the reform most crucial to him was the improvement of the territorial representation of stateless nations, such as Scotland. As he argued at the Convention, not only would this involve improving the representation in the EP of "electoral constituencies that recognize areas with a distinctive sense of national or regional identity." ${ }^{42}$ It would also require a redefinition of the scope and mandate of the Committee of regions, and, more generally, an institutional reform authorizingand actually imposing - systematic consultation by European institutions of such regional entities alongside member states. For instance, he proposed that voting rights of each member state at the Council might be split to allow for divergent expressions of regions within a state. Crucially, then, the proposed reform would not only be at EU level; it would involve a better representation of regions within states themselves and allow for "internal enlargement." 43 This would effectively turn the Council into a second chamber representing territories rather than states.

Such reforms would bring the EU close to the normative model of "demoi-cracy": In this view, the EU is composed of different demoi not likely to become one single European demos in the near future and whose diversity is valuable. ${ }^{44}$ But those demoi are not only the people of nation-states; they also comprise regional entities. However, this focus on subsidiarity as regional representation does not mean that other reforms drawing on other ideas of democracy and subsidiarity should not be undertaken - for instance, by improving direct participation of citizens. In fact, he at times seemed to endorse a more maximalist version of democracy, suggesting that the term subsidiarity, like democracy, can receive different meanings and take different forms ${ }^{45}$ Ideally, it would then be necessary to integrate these different ideas and practices to the EU's institutional architecture, but his immediate concern for territorial subsidiarity echoed his already mentioned life-long commitment for Scottish nationalism, and its practical concern for EU reform.

\footnotetext{
${ }^{39} I d$. at 147.

${ }^{40}$ On this concept, see Will Jordan \& Scott Yenor, Federalism and David Hume's Perfect Commonwealth, in THE AsHGATE Research Companion to Federalism 121 (Ann Ward \& Lee Ward eds., 2009).

${ }^{41}$ Richard Bellamy, A Republican Europe of States: Cosmopolitanism, InTERgovernMENTALISM AND DEMOCRACY IN THE EU 12 (2019).

${ }^{42}$ Neil MacCormick, Contribution présentée par M. Neil MacCormick, Membre suppléant de la Convention : Démocratie à de Multiples Niveaux: Réforme Constitutionnelle Européenne, Historical Archive of European Integration, Florence, CONV 298/02, 2-5 (2002).

${ }^{43} I d$. at 2.

${ }^{44}$ See generally Kalypso Nicolaïdis, The Idea of European Demoicracy, in PHILOSOPHICAL Foundations OF EUROPEAN UNION LAW 247 (Julie Dickson \& Pavlos Eleftheriadis eds., 2012).

${ }^{45}$ MACCORMICK, supra note 15 , at 155.
} 


\section{Cosmopolitanism Through Civic Nationalism}

This leads directly to the question of nationalism. With the emergence of European citizenship in 1992, many wonder: To what extent will citizens need to support and feel loyal to the EU for it to operate legitimately? In a national sovereignist vein, many have argued along with the German constitutional court that the EU could not be a proper democracy because it lacked a demos, that is, a people bound together by a shared culture, language, and history and thus able to build up trust, solidarity, and a genuine civic dedication to the common good. ${ }^{46}$ To that claim, others have replied in a Habermassian perspective that such a thick, shared ethos is not necessary for a democratic EU to develop. Rather, what is necessary is a post-national, self-reflective respect for the principles embedded in European law. ${ }^{47}$ But, as critics have invariably stressed, this constitutional patriotism provides only a very thin basis for citizens' mobilization. It is likely to remain a noble, but impracticable, ideal.

MacCormick took an intermediate stance in this debate. He endorsed a version of constitutional patriotism, arguing that the EU might rest on "a civic demos, one identified by the relationship of individuals to common institutions" rather than on some preexisting people. ${ }^{48}$ There are, however, specific conditions for even such a limited ethos to develop. In particular, European citizenship plays a central role. A shared status "gives us a basis for acknowledging each other as fellow members in the same enterprise," and thus as sharing common values and interests. Yet, he remarked, European citizenship in turn depends on national belonging. Formally, European citizenship "does not cancel, but presupposes, the distinct peoplehoods of the different peoples of the member states." ${ }^{\prime 9}$ More substantively, not only are nations necessary as a basis of a thin status of European citizens; if the EU were to become more democratic, it would imply rehabilitating nations in a stronger sense. It is at this point that MacCormick departs from many postnational theses.

To understand this move, we need to look closer at his theory of liberal nationalism, which is much in line with both Hume's theory of sympathy and the Scottish tradition of civic nationalism. ${ }^{50}$ It strives to reconcile communitarian and liberal sensibilities. On the one hand, it endorses the familiar communitarian criticism of liberalism: Liberalism operates with an abstract idea of individuals. ${ }^{51}$ In reality, from beginning to end, "humans as moral and practical beings have ties and links of sympathy and fellow-feeling with other individuals."52 "Sympathetic" individuals can only be apprehended in a specific social context that provides the actual motivational basis for their decisions. ${ }^{53}$ And obviously, nations have been an important part of this context. On the other hand, acknowledging this constitutive role of national context is compatible with a liberal emphasis on individuals and rights. For nations are "imagined," and sometimes deeply valued, by individuals. Therefore, nations should also be respected according to liberal standards of respect for individual beliefs and values. This is the principle of "personal nationalism." 54

In line with this theory, MacCormick spelled out a normative idea of nations as "cultural, but not necessarily ethnic, communities of persons conscious of their attachment to a country-a

\footnotetext{
${ }^{46}$ Dieter Grimm, Does Europe Need a Constitution? 1 Eur. L. J. 282, 290 (1995).

${ }^{47}$ See Jürgen Habermas, The Postnational Constellation: Political Essays 74-76 (Max Pensky ed., 2001); Justine Lacroix, For a European Constitutional Patriotism, 50 POL. STUD. 944 (2002).

${ }^{48}$ MACCORMICK, supra note 15 , at 144 .

${ }^{49} \mathrm{Id}$. at 145.

${ }^{50}$ See Jonathan Hearn, Claiming Scotland: National Identity and Liberal Culture Ch. 8 (2000).

${ }^{51}$ See Charles Taylor, Atomism, in Philosophy and the Human Sciences: Philosophical Papers 187 (Charles Taylor ed., 1985).

${ }^{52}$ MACCORMICK, supra note 15 , at 180.

${ }^{53}$ See Yael TAmir, Liberal Nationalism 13-34 (1993).

${ }^{54}$ See Anthony Cohen, Personal Nationalism: A Scottish View of Some Rites, Rights, and Wrongs, 23 AM. ETHNOLOGIST 802 (1996).
} 
geographical space-and its civic institutions and culture." ${ }^{55}$ Importantly, here, ethnic properties are not essential to the concept of nation. Rather, for-MacCormick those defining features are, above all, the civic institutions organizing the community. For institutions are regarded as a historical-cultural product of social life. They publicly express the nation and its values. With this emphasis on institutions, "the point of the idea of a civic nation is that it is in principle open to voluntary membership." ${ }^{56}$ Civic nations are open to voluntary adhesion and exit on the basis of an individual's assessment of their institutions and values. ${ }^{57}$ Reciprocally, being a member of a civic nation implies a real concern for the institutions and the common good they are meant to secure. In this sense, the civic nation is tightly connected to the republican idea of civic virtue as the disposition of citizens to "prefer the good of their community to all other goods." 58

Now, what this suggests for the EU is something akin to a "grounded" version of constitutional, or rather civic, patriotism. ${ }^{59}$ It avoids the abstract character of constitutional patriotism by connecting it to an actual national context. But at the same time, it tries to avoid the exclusionary effect of traditional nationalism by redefining the nation in a civic sense. So defined, nations provide the relevant civic community in which a strong civic virtue can develop. This virtue would unfold at the national, not European level. Yet, because of its open character, and its civic orientation, it would not have to conflict with other nations nor with the EU, provided that their civic institutions share some basic features. In combination with subsidiarity civic nationalism and European patriotism might even prove mutually reinforcing. While subsidiarity would satisfy nationalists by granting more power to nations, it would also legitimize that certain issues be dealt with at the European level, where they are more likely to find adequate solutions. Civic virtue at the national level would thus combine with well-understood interest to support European integration.

In this view, however, one might want to ask what is distinctive of nations. For other types of communities corresponding to this civic definition of the nation could be imagined: Associations, political movements, et cetera. But MacCormick mostly focused on nations. This is so because, as he remarked, nations have historically played a preeminent political role. ${ }^{60}$ Yet, even if one is to agree with this statement-and the case of, say, religions should be more carefully discussed here-it is a historical argument. Nothing prevents, in theory, other types of communities from cementing such a strong civic sense. There is no intrinsic moral privilege of nations ${ }^{61}$-an idea that seems to lead straight to a kind of cosmopolitanism. ${ }^{62}$

\section{Stability Through Virtuous Rulers}

Finally, the model developed by MacCormick is not only concerned with the institutional design or the ethical dispositions of citizens. It also invites consideration of the ethical dispositions of those who exercise power-the rulers - as an element for a post-sovereign polity to maintain itself. Once again, MacCormick was in line with Hume's political thought. According to Hume, even a perfect Commonwealth could not completely disregard the question of the personal qualities of its rulers. However carefully it might have been designed, it is always possible that the

\footnotetext{
${ }^{55}$ MACCORMICK, supra note 15 , at 182.

${ }^{56} \mathrm{Id}$. at 170.

${ }^{57}$ See John Erik Fossum, Nationalism, Patriotism and Diversity-Conceptualising the National Dimension in Neil MacCormick's Post-Sovereign Constellation, in LAW AND DEMOCRACY IN NEIL MACCORMICK'S LEGAL AND POLITICAL Theory: The Post-Sovereign Constellation 271 (Augustin Menéndez \& John Erik Fossum eds., 2011).

${ }^{58}$ Quentin Skinner, MaChiavelli 62 (1981).

${ }^{59}$ See Cécile Laborde, From Constitutional to Civic Patriotism, 32 BRIT. J. POL. SCI. 592 (2002).

${ }^{60}$ See Neil MacCormick, Liberalism, Nationalism and the Post-Sovereign State, 44 Political STUdies 553, $553-67$ (1996).

${ }^{61}$ See Neil MacCormick, Legal Right and Social Democracy: EsSaYs in Legal and Political Philosophy 252 (1982).

${ }^{62}$ See Fossum, supra note 57, at 264; Martha Nussbaum, The Cosmopolitan Tradition: A Noble but Flawed Ideal 29 (2019).
} 
polity goes through "unusual times," that is to say, times of crises that will require the rulers to enter uncharted territory to make decisions. ${ }^{63}$

And indeed, the theory of constitutional pluralism has tended to emphasize the possession of certain ethical dispositions by rulers in critical times. It was mostly concerned with a special case of crisis-that of conflict between judicial entities, the original context of this reflection being, after all, the Maastricht ruling of the German constitutional court. ${ }^{64}$ But even so, there seems to be no reason why it should not have a broader scope. MacCormick made clear that thinking about critical situations could not be satisfied with pure institutional design, precisely because such situations escape the established legal framework. ${ }^{65}$ Instead, he appealed to a normative nonlegal order to prevent their apparition. In other words, certain virtues are expected of rulers. For instance, judges should make use of "circumspection and [of] political as much as legal judgment," and should recognize when their claims are going to lead to practical deadlock rather than the common good. This is not specific to MacCormick. Likewise, for instance, Joseph Halevi Horowitz Weiler famously argued for a practice of constitutional tolerance, dialogue, and sincere cooperation between judges and courts. ${ }^{66}$ It is in ethical, rather than legal, language that the problem of crisis is ultimately addressed in a constitutional pluralist perspective.

But what if crisis cannot be prevented? Admittedly, this question has been downplayed by MacCormick. However, in such a critical situation, too, I posit the answer would be that prudence of rulers, as distinct from pure formal or procedural guarantees, is necessary for a post-sovereign entity to avoid falling into chaos or dictatorship. Early on, MacCormick had emphasized that, to face difficult cases, a good judge should not only master legal knowledge, but also possess certain human virtues. ${ }^{67}$ In discussing the bureaucratic-aristocratic element of the EU's mixed constitution, he was more specific in pointing out that "wisdom in practical affairs, prudentia, seems to be very differentially distributed among us . . . [and] identifying the common good and the means of its pursuit is not an easy task, and only wise and experienced persons are likely to be good guides." ${ }^{68}$ A good ruler needs some degree of prudence, that is, of practical wisdom and experience.

It is worth noting that prudence is not purely defined in terms of civic virtue. It is not only because they are concerned with the common good that they are praised as "good guides." It is also because they are not sheer incompetents, or pure ideologues unconcerned with practical matters. In case of crisis, in the last analysis, it is on this combination of moral dispositions that much will depend. Prudence, so defined, will make sure that rulers are concerned with the common good, and do not seize power for themselves. It will also guarantee that their practical decisions are based on "wisdom and experience", and therefore likely to be good in practice. Importantly, this not only applies to EU judges, but also to national ones. National judges should consider the consequences for the great "Commonwealth" and for themselves as part of it, of the decisions made in the "small republics." A post-sovereign Commonwealth thus requires a kind of double ethical commitment from judges and, more generally, rulers: A commitment to the common good of the small republics, and to the common good of the European Commonwealth.

Thus, the theory of MacCormick requires complementing institutional design with a certain substantive virtue of rulers in times of crisis. Indeed, in this sense, it does mark a shift away from liberalism and its thin ethical requisites. Yet, this does not lead to total uncertainty and chaos as critics would have it. The prudence of rulers is meant to ensure some degree of predictability even

\footnotetext{
${ }^{63}$ Hume, supra note 33 , at 229.

${ }^{64}$ MACCORMICK, supra note 15 , at 174.

${ }^{65}$ MacCormick, supra note 14 , at 271.

${ }^{66}$ See Joseph Weiler, In Defence of the Status Quo: Europe's Constitutional Sonderweg, in EUROPEAN CONSTITUTIONALISM Beyond the State 18 (Joseph Weiler \& Marlene Wind eds., 2001).

${ }^{67}$ See Neil MacCormick \& Ota Weinberger, An Institutional Theory of LaW: New Approaches to Legal Positivism 205 (1986).

${ }^{68}$ MACCORMICK, supra note 15 , at 146.
} 
when the law is no longer able to. This might appear as a much weaker guarantee against abuses of power than legal dispositions and institutional design, but in times of crisis when no legal disposition holds, this is supposed to allow citizens to build expectations about how they are going to act. Interestingly, if we follow MacCormick here, these expectations will a minima be that rulers actually pursue the common good in a reasonable way. Therefore, even though this virtue is not described in classical republican terms, ultimately, it resembles-in practice at least-traditional republican conceptions of civic virtue.

To summarize, in light of this examination of MacCormick's political thought, the first interpretation of constitutional pluralism misses the point when claiming that it can be understood as yet another version of rights-based cosmopolitanism, hardly concerned with democracy, and only offering a weak legal scheme. Instead, we saw that, while he stressed that the EU was not completely undemocratic, he was deeply interested in its democratic strengthening. Besides, far from being a purely legal one, his project was of a deeply political nature. Symmetrically, the second interpretation is misled in seeing it as intrinsically illiberal. His nationalism is of such an open texture that it should, in fact, prevent any ethno-nationalist interpretation contradicting liberal principles. Moreover, the risks for the rule of law identified by the critics, while they cannot be completely disregarded, are supposed to be prevented by the ethical dimension of his project. Virtuous rulers should ensure stability and legal security when the law and the institutions are most likely to fail this task, that is, in critical times. Therefore, it is possible to interpret the political theory of constitutional pluralism while avoiding the dangers pointed out by critics of the two readings identified above.

\section{E. Conclusion}

This Article has explored the political theory underlying the legal doctrine of constitutional pluralism. It has examined two common interpretations of this theory and their criticisms: Constitutional pluralism as a form of liberal cosmopolitanism, and as an inherently illiberal nationalist theory. By carefully reading the political thought of one of the founders of constitutional pluralism, MacCormick, this Article has argued that neither interpretation did justice to the normative political thought he developed. In his understanding at least, it is neither a purely liberal nor a purely illiberal theory. This does not mean that some later versions of the theory, developed by other authors, cannot be. Rather, this is to say that constitutional pluralism as developed by MacCormick provides conceptual tools to evade this opposition. Indeed, I have suggested that the theory was precisely designed to overcome such binary oppositions. It conceives a form of cosmopolitan nationalism - itself compatible with the idea of demoi-cracy. ${ }^{69}$ Moreover, the emphasis on civic virtue brings the theory close to republicanism. All in all, if we consistently follow the path forged by MacCormick, we are most likely to arrive at a form of republican cosmopolitanism leading towards a loose European, and potentially global, confederation.

That constitutional pluralism does not have to be understood as a form of liberal rights-based cosmopolitanism, nor of illiberal nationalism, is of some importance for the EU. Of course, one might find comforting not to discover a dangerous illiberal theory at the heart of the EU legal doctrine and practice. However, one might also find disturbing that a theory that seems to have gained so much ground, in the EU and beyond, departs from liberal principles. To take but one example, the ethical dispositions needed of rulers in the event of crisis might appear like a very weak safeguards of individuals' rights and freedoms. Yet, in a time of deep challenges to political liberalism, both at home and abroad, ${ }^{70}$ this could also open up promising avenues to renew a

\footnotetext{
${ }^{69}$ Jan-Werner Müller, The Promise of Demoi-cracy: Democracy, Diversity and Domination in the European Public Order, in Political theory of the European Union 187, 200 (Jürgen Neyer \& Antje Wiener eds., 2010).

${ }^{70}$ See generally G. John Ikenberry, The End of Liberal International Order?, 94 INT'L AfF. 7-23 (2018); MANUEL CASTELLS, Rupture: The Crisis of Liberal Democracy (Rosie Marteau trans., 2018).
} 
political and theoretical debate that, at times, seems hypnotized by the divide between liberal cosmopolitans and illiberal nationalists. Moreover, emphasizing the issue of the virtues of rulers, as I suggested the theory does, invites us to pay attention to the possible shortcomings of the "supplyside" of political activity in these times of crisis. ${ }^{71}$ In other words, it invites us to take issue with the behavior of rulers and to make them accountable, instead of having the citizens bear exclusive responsibility for the crises. In this sense, it could help bridge what seems to be a growing gap between peoples and their national, as well as European, rulers.

\footnotetext{
${ }^{71}$ Colin Hay, Why We Hate politics 59 (2007).
}

Cite this article: Canihac H (2021). Is Constitutional Pluralism (Il)liberal? On the Political Theory of European Legal Integration in Times of Crisis. German Law Journal 22, 491-505. https://doi.org/10.1017/glj.2021.22 